\title{
Exploring Approaches to Italian Early Medieval Archaeology in Post-communist Europe
}

\author{
Giulia Vollono
}

University of Sheffield

\begin{abstract}
The fall of the Berlin Wall and, subsequently, of communism in Europe had profound consequences for the social and political environment of many European countries, including Italy. In this paper I discuss the impact that these, now historical, events and the new socio-political arena that emerged in their aftermath had upon Italian Early Medieval Archaeology from two interconnected perspectives. On the one hand I consider the history of a discipline that, although strongly characterised by a Marxist approach at its birth, appears not to have been subject to significant changes in its theoretical outlook as a consequence. On the other, through a consideration of the changing character of major exhibitions on the Lombard period, I explore the role that archaeology has played in the construction of a transnational European narrative in a post-communist Europe while maintaining a central role in the negotiation of local identities. The ultimate aim of this paper is to re-evaluate the latest developments in Italian archaeology from a fresh perspective, considering the impact that major contemporary events can have on our perception, interpretation and narration of the past.
\end{abstract}

Keywords: Early Medieval Archaeology, Lombard Italy, Post communism, Exhibitions, Identity.

\section{Introduction}

This paper was presented at the $20^{\text {th }}$ EAA conference as part of the session Impact of the Fall of Communism on European Heritage ${ }^{1}$. It focuses on developments in Italian

\footnotetext{
${ }^{1}$ Many thanks are due to the organisers of the EAA conference session and editors of this volume, Dr. Maja Gori and Professor Valerie Higgins, for their enthusiastic reception of this paper and their encouragement in bringing it to publication. I am especially grateful for their insightful criticism and comments, and the patience they showed during the editorial process. Thanks are due also to an anonymous reviewer for critically reading the manuscript and providing useful suggestions to improve it. My attendance and participation in the conference was made possible by sponsorship from the Petrie Watson Exhibitions, University of Sheffield, to which I am very grateful. Grateful thanks are also due to the Arts \& Humanities Research Council and The University of Sheffield whose award of a scholarship have allowed me to undertake the doctoral research that inspired this paper, and to Professor Dawn Hadley and Professor John Moreland for their invaluable advice and supervision. Special thanks go to Professor John Moreland for the stimulating discussions on archaeological theory and Medieval Archaeology over the years and for his comments on this paper. I am also grateful to Dr Mark Peters for his support during this research, the fruitful exchange of ideas on the topic and for editing my English. Thanks are due also to Dr Alessandro Sebastiani and Angela Catania who kindly gave their thoughts and opinions.
} 
Medieval Archaeology over the last 40 years, reflecting on how major contemporary social and political events may or may not have influenced the themes and approaches that have characterised the development and maturation of the discipline. The case that I present here developed out of research being conducted on the archaeology of Lombard Italy for my doctoral thesis and, particularly, on processes of identity construction $^{2}$. These are preliminary thoughts, first reflections on a complex and multifaceted subject that is, in my opinion, deserving of greater consideration and critical analysis. They are offered here as the first steps into what promises to be a fruitful and enlightening debate.

In this contribution I argue that Early Medieval Archaeology in Italy remained, apparently, immune to the substantial political, social and economic changes that followed the fall of the Berlin Wall. While the theoretical roots of the discipline were deeply embedded in Marxism, the academic world in Italy continued to pursue its own research themes and approaches despite the events of the late 1980s and 1990s and the changing intellectual environment they brought about. However, in analysing the organization of major exhibitions on the Lombard period as a case study, I further argue that many of the issues resulting from the fall of communism, such as the construction of a new European identity, the renegotiation of regional identities and the place of local communities in this new socio-political landscape found expression in higher profile events that were targeted towards the wider public. I then briefly reflect on the latest developments of the discipline in the face of the new challenges that European countries have been experiencing since the turn of the millennium.

Before exploring the nature and character of Early Medieval Archaeology it is first necessary to briefly summarise the main consequences of the end of communism in Europe and what impact they had upon the political landscape of Italy. The fall of the Berlin Wall represented the end of a perception of the world that had prevailed since the conclusion of the Second World War. The opposition between the Eastern and Western Blocs suddenly and dramatically ceased to exist with consequences on many socio-political levels. Europe was no longer physically and geographically divided, allowing greater freedom of movement and communication between countries than had been seen before. The clash between western capitalism and the communist system disappeared and with that the constant threat of imminent conflict. The countries formerly of the Eastern Bloc, abruptly relabelled as central European, witnessed massive social and political changes that inevitably challenged their identities, sometimes with dramatic consequences. From the fall of the Wall a new, complex and socially mobile Europe emerged, no longer defined by a simple dualism between east and west, with each country having to renegotiate its own identity and relationships with this dynamic, mutable entity.

Towards the end of the 1980s and the beginning of the 1990s the political landscape in Italy also changed considerably: the communist party, founded in 1921, ceased to exist partly as a direct consequence of the collapse of the Soviet Union. In 1993 a substantial 'kickback scandal' involving major political figures, ultimately, brought about the

${ }^{2} \mathrm{My} \mathrm{PhD}$ project, entitled Constructing identity in Lombard Italy, is currently on-going in the Department of Archaeology of the University of Sheffield. 
demise of the Socialist party. A year later the Democrazia Cristiana, a moderate party who had either formed or been an integral part of the Italian government since 1944, dissolved into smaller and much less successful groups. All of these events combined to completely transform a political situation that had been in place since the end of the Second World War and so brought to an end the so-called 'First Republic'. From its ashes a number of new political parties emerged that would populate the Italian political stage for the next 20 years. For example, the Lega Nord, a secessionist and populist party, Alleanza Nazionale, heir of the post-fascist parties and Forza Italia a new political project led by Silvio Berlusconi. Onto this stage a series of more-orless left-wing parties also appeared, who became progressively more moderate (for an overview and discussion of the Italian political situation in this period see e.g. Gundle \& Parker 1996).

\section{Medieval archaeology in Italy}

It would be reasonable to suppose that such socio-political turmoil following the collapse of communism, both on a national and international scale, might have had significant consequences on the cultural aspects of Italian society, including the way in which archaeology was conducted. Indeed, such ideas are strengthened when we consider the theoretical framework in which Italian Medieval Archaeology operated when established as an independent discipline in the 1970s.

Arguably, the event that, at least symbolically, marked the birth of Italian Medieval Archaeology was the publication of the first issue of the journal Archeologia Medievale in 1974. The editorial of this inaugural issue (ArchMed 1974) was in all respects a manifesto aimed at defining the boundaries of the discipline and its approaches. As others have already noted (Delogu 1986: 499; Augenti 2003: 515; Brogiolo 2009: 155), the Marxist philosophy behind these few pages is self-evident: historical periodization was to be based on "the transformations of the means and relationships of production" (ArchMed 1974: 7, my translation). Emphasis was placed on the study of the production, distribution and consumption of goods in connection with historical processes with the aim of accessing and studying the "subordinate classes" (ArchMed 1974: 8, my translation). This declaration included the history of settlement as well as that of landscapes, to investigate people's technical and economic relationship with the environment.

These were, in fact, the themes that were to become predominant in Medieval Archaeology. From the 1980s onwards a significant amount of data was collected both from the excavation of fortified sites and villages in rural areas and also from urban contexts, brought about by redevelopment activities and archaeological risk assessments. Research in those years became focussed especially on the history of settlements and landscapes dating from the late antique period to the tenth and eleventh centuries (e.g. Hudson 1981; Brogiolo 1984; 1987; La Rocca 1986; Francovich \& Milanese 1990).

These lines of enquiry were further developed in the 1990s when the data collected during the 1970s and 1980s, alongside more recent excavations, were frequently reworked to present synthetic discussions on specific themes or geographical regions (for an overview of the main themes that characterise the history of Medieval Archaeology in Italy see Gelichi 1997; Pani Ermini 2000; Brogiolo 2009). The need 
to reflect upon the achievements and developments of two decades of Medieval Archaeology and synthesise its results is visible in the high number of seminars and conferences that were held and published during the 1990s (for significant examples see, e.g. Francovich \& Noyé 1994; Brogiolo 1995, 1996; Brogiolo \& Cantino Wataghin 1998). This reorientation of the Marxist approach, so explicitly defined in 1974 but now less openly referred to, did not bring about any corresponding debate and discussion over the theoretical framework of the discipline. As Brogiolo (2009: 156) has argued, developments in Italian Medieval Archaeology, and its contribution to the international debate, had (and continue to have) more to do with new methodological applications, in particular computerization and the systematic application of scientific analyses to material culture, than with theoretical debate.

In contrast with the situation in other countries Medieval Archaeology in Italy was largely unaffected by the emergence of post-modern theoretical frameworks of interpretation. These new approaches, which were partly the result of the advent of a new world and which encompassed all of the uncertainty that such dramatic historical changes provoke, did not catch on. Early Medieval Archaeology was, instead, experiencing a phase of 'positivism' where the principles developed by the processual tradition were applied. The lack of theoretical debate in general and the coldness towards the paradigmatic shift brought about by post-processualism in particular, has been acknowledged by several scholars over the years (e.g. Augenti 2003: 213; Brogiolo 2009: 156 Gelichi 2011: 10-11; 2015). Brogiolo (2009: 156), for example, explains this direction in Italian Medieval Archaeology through a combination of reasons that he sums up by observing:

\section{"in that period, the most important problem to solve was that of the development of an archaeological discipline interested not just in the study of artefacts of art-historical relevance, but aimed at the reconstruction of complex stratifications through a multi- disciplinary approach."}

Certainly, this is a complex topic, which extends across the discipline of Italian archaeology as a whole (Augenti 2003: 213; Gelichi 2015: 8). Indeed, the diverse but interrelated factors that may have determined this stagnation in the theoretical debate are deserving of more careful consideration and in depth analysis that are possible within the scope and purpose of this paper.

\section{A case study: presenting the Lombards to the public}

It would appear from this brief overview that academic archaeology in Italy was, to all intents and purposes, untouched by the wider social and political changes that resulted from the fall of the Berlin Wall. However, when we shift our attention from the way in which archaeology was conducted to the ways in which it was presented, we begin to see that the effects of these momentous events did indeed filter through and have profound consequences. In this respect major exhibitions are particularly revealing and provide a good source through which we can view the relationship between scholarly work and contemporary society. This connection is strengthened by the fact that the curators and organisers of exhibitions are, themselves, often members of the 
academic community. It can be argued that while the socio-political changes of the last thirty years did not greatly influence the wider theoretical framework of Medieval Archaeology in Italy they did have an impact on the interpretations and narratives produced by Italian scholars and that this change in perspective is most noticeable in events directed towards the general public.

A possible explanation of this phenomenon is that to be successful, marketable and financially viable exhibitions have to present timely topics that are perceived as important by the scholarly community and non-academics such as the general public, sponsors and local institutions alike. These exhibitions also need to present coherent and accessible journeys into history, which are, by necessity, simplified versions of the more complex 'deliberations of the specialists'. As such, the objects put on display, as well as the texts that accompany them, are carefully chosen to convey meaningful messages for the public. In these types of arenas the link between past and present concerns is inevitably more conspicuous. It is also important to emphasise that these messages are then fed back into the academic community, which make extensive use of exhibition catalogues as sources for students as well as for research purposes. To explore the implications of these observations it is worth examining some of the major exhibitions on the history and archaeology of the Lombards held in Italy since the 1970s.

It was at end of the sixth century that the Lombards first arrived in the Italian peninsula and proceeded to gradually establish dominion over some of its territories. In 774 they were defeated by Charlemagne and the northern part of the Lombard kingdom was annexed to the Carolingian Empire (for a synthesis of the Lombard migration, see for example Rotili 2010; for a discussion on the history of the Lombard kingdom in Italy, see Delogu 1980). Considered as a Germanic group which, according to the written sources, originally came from Scandinavia, the Lombards have been the focus of contentious debate since the fifteenth century (for an overview of the debate see, Falco 1952; Artifoni 2000). Recent work on the development of Lombard studies (e.g. Barbiera 1998; 2012: 82-92; La Rocca 2008) has shown that, although interest in the period has been intermittent, the Lombards have been variously portrayed as a barbaric, cruel and alien population or as illustrious ancestors. Interpretations of the Lombard period, arguably more so than for any other historical period, seem to be closely associated with more general issues surrounding Italian identity and the construction of local and national historical narratives.

Since the 1950s and 1960s, the importance of the Lombard period for the formation of modern Italian culture has been re-evaluated. It is now generally considered to be the result of the melding of Germanic and Latin cultures, a process that began in the seventh century aided by the Church and the conversion of the Lombards to Catholicism (e.g. Delogu 1980: 44-51; Pugliese Carratelli 1984; Gasparri 2005: XVI-XVIII). This perspective on the Lombards was also presented to the public in two major exhibitions, I Longobardi e la Lombardia (The Lombards and Lombardy), held in Milan in 1978 (Arslan et al. 1978a; Arslan et al. 1978b) and I Longobardi (The Lombards) held in Cividale del Friuli in 1990 (Menis 1990a). In these exhibitions, the history of the Lombards was portrayed as an evolutionary process, from the period of their settlement in Pannonia and the invasion of Italy, through the seventh century 
when acculturation took place, to the eighth century when an evolved society that could finally be defined as Italian, flourished. The main lines of evidence presented in support of this reconstruction were changes in material culture and funerary practice, the transition from oral to written traditions, and developments in architecture mainly expressed in the foundation of churches and religious institutions (e.g. Cavanna 1978; Menis 1990b; Hessen 1990; Pavan 1990; Scardigli 1990).

A decade on from the Cividale event another major exhibition was held in the city of Brescia in Lombardy (Bertelli \& Brogiolo 2000a, 2000b). Its title, Il Futuro dei Longobardi. L'Italia e la Costruqione dell'Europa di Carlomagno (The Future of the Lombards. Italy and the Construction of Charlemagne's Europe, my translation) clearly reveals the adoption of a new perspective by the organisers: the Lombards as significant agents in the construction of Europe. Of course it was around this time that the European Union project, as we know it today, was having tangible effects and impacting significantly on the everyday - as well as political- lives of people across Europe in the wake of the collapse of the East-West divide. In 1990 Italy signed the Shengen agreement, which ratified the abolition of border checks between subscribing European States. Two years later, in 1992, together with the other twelve countries, Italy signed the Maastrich treaty that established the European Union and in 1999 the process to replace the Lira with the Euro began (Unione Europea 1990-1999). The 1990s also witnessed a progressive increase in the involvement of Europe in the cultural life, research and heritage management of European member states (Tzanidaki 2000; Niklasson 2013: 55-60). This emphasis on European history, culture and heritage is exemplified by exhibitions and research projects across Europe, which focussed on what were perceived as crucial moments in its history. Significant examples are the exhibitions on the Franks, held in Mannheim, Berlin and Paris between 1996 and 1997 and the project The Bronze Age- the First Golden Age of Europe (Gramsch 2000: 11-13; 2013: 26; Marin 2001; Wood 2013: 319).

In creating a super-national organism such as the European Union there was a perceived need among its architects to identify a shared common past that, at the same time, respected the singular histories and identities of its members in agreement with the European motto 'Unity in Diversity' (for a critical discussion of this phrase see Shore 2006). Presenting the 'barbarian' kingdoms of Late Antiquity and the Early Middle Ages as the origin of a European koiné that culminated in Charlemagne's Holy Roman Empire offered a seemingly acceptable and appropriate model for the European Union. As the latter is the product of complex and diverse contributions from the many nation states that it encompasses, Charlemagne, in apparently managing to unify and synthesise multiple regional traditions, provided a clear historical precedent.

Consequently, the Lombards of the seventh and eighth centuries were presented by the organisers of the Brescia exhibition as the channel through which classical culture could be absorbed into the Holy Roman Empire. Lombard society appeared as a rich and prosperous multi-ethnic organism, which managed to assimilate and shape Roman heritage into new forms and, hence, could be seen as giving birth to a Lombard Renaissance. This viewpoint emerges from the introduction to the catalogue by Jacques Le Goff (Bertelli \& Brogiolo 2000a: V-VI), the scientific director of the subsequent series of exhibitions that went under the name of Charlemagne. The Making 
of Europe. Alongside Brescia, the cities of Paderborn, Barcelona, Split and York hosted exhibitions, which Alberto Forlani, president of the Fondazione Banca Credito Agrario Bresciano, one of the sponsors, stated in the introduction to the exhibition were

"to show the variety of regional contributions that were synthesised in the political construction made by Charlemagne and his successors" (Bertelli \& Brogiolo 2000a: III). ${ }^{3}$

This new perspective on the Lombards was not only expressed through the scholarly essays published in the accompanying monograph (Bertelli \& Brogiolo 2000b), but also through the choice of objects that were exhibited (Bertelli \& Brogiolo 2000a). Particular attention was devoted to Lombard written culture through the presentation of manuscripts and inscriptions. Similar emphasis was placed on sculpture and those metal objects that demonstrated classical influences. This included the famous Valdinievole plate linked with king Agilulf who, at the beginning of the seventh century, began to adopt the symbols of Byzantine royalty and situated himself closer to Catholicism and the Pope (e.g. Delogu 1980: 39-44; Kurze 1980; Bertelli 2000). A wider European gloss to the exhibition was achieved through the inclusion of items originating from other countries that testified to the contacts and influence that Lombard Italy had beyond the Alps.

The location of the exhibition in the complex of Santa Giulia was, itself, highly significant. Founded in 753 by Desiderius, who would become the last king of the Lombards, and his wife Ansa, this monastery has been considered a marker of a refined and civilised Lombard elite who were fervently Catholic and prepared to invest in elaborate works of art, as can be seen in the decoration of the church of San Salvatore. In general, all of the locations in which these exhibitions were held are meaningful in Lombard history: Cividale del Friuli, the first city conquered by the Lombards and the capital of their first duchy; Milan that was the capital of the Lombard kingdom at the beginning of the seventh century; and finally Brescia, centre of another important Lombard duchy that preserves, as we saw, some of the architectural expressions of the period.

In this respect we can see here how, through a single event, different identities were expressed simultaneously. At the widest, most inclusive level, we are witness to a supernational European identity that sees the Lombards as a channel for the transmission of classical and Christian culture into Medieval Europe. On a more localised level the Italian national identity is presented as deriving from the merging of the Church, Roman and Germanic heritage. Finally, in harmony with the staging of this and other exhibitions, we see the portrayal of local identities in which the Lombards are shown as ancestors of the inhabitants of specific localities within Italy.

I suggest that the emphasis on multiple identities as well as the need to integrate Italy into a wider European context represents, in many respects, an answer to the new world that emerged during the 1990s. This was a globalised world in which boundaries and simple dualisms melted away and the static opposition that existed between two philosophically divergent blocs apparently disappeared. The narratives on the Lombard

\footnotetext{
${ }^{3}$ Translation from Italian by GV.
} 
period presented in these exhibitions downplayed the negative aspects that can result from the encounter of cultures, the simplistic dualism between 'barbarian' and Roman, and managed to resolve the opposition between the classical and the Germanic worlds. An interesting postscript to this is the acknowledgement of the role that the Lombards played in the construction of Medieval Europe from another intergovernmental institution. In 2011 seven monumental sites dated to the Lombard period were registered in the UNESCO's World Heritage list under the title Longobards in Italy. Places of Power (568-774 AD). The sites are: the Gastaldaga area and the Episcopal complex in Cividale del Friuli (Friuli Venezia Giulia); the monastic complex of San Salvatore and Santa Giulia in Brescia (Lombardy); the castrum with the Torba Tower and Santa Maria Foris Portas at Castelseprio (Lombardy); the basilica of San Salvatore in Spoleto (Umbria); the Clitunno Tempietto at Campello sul Clitunno (Umbria); the Santa Sofia complex in Benevento (Campania); the sanctuary of San Michele at Monte Sant'Angelo (Puglia; UNESCO 2011a:7). As the inclusion of sites on the World Heritage list is usually proposed by single States members of the UNESCO, this is further evidence of the desire of Italian experts and institutions to project a specific image of the Lombard period and, thus, of Early Medieval Italy, integrating it within European history (UNESCO CNI). The fact that the proposed application was successful also suggests that this view of Lombard Italy was shared internationally and that some of the material remains of the period are considered to have 'an exceptional and universal value' beyond national borders (UNESCO 2011b). The motivations behind this decision are eloquently stated in the UNESCO's website:

\begin{abstract}
"A people of Germanic origin, having settled and converted to Christianity, the Lombards assimilated the material and cultural values inherited from the end of the Roman world. Also in contact with Byzantine, Hellenistic and Middle Eastern influences, the Lombards achieved a cultural, architectural and artistic synthesis, unique in terms of its monumental and stylistic diversity and the various secular and religious uses. It is one of the main roots of the beginnings of the medieval European world and the establishment of Western Christianity." (UNESCO 2011b).
\end{abstract}

However, in the last decade we have experienced further changes and complications. The European project, as envisaged in the 1990s, has encountered significant problems and the current economic crisis is aggravating the substantial differences between its members. Globalization, too, has added to the general socio-political difficulties and further emphasised issues such as identity and exposed the tensions between local, regional, national and supra-national interests.

It is entirely plausible to suppose that these difficulties are reflected in the revival of discussions surrounding the fall of the Roman Empire and the Migration Period. To simplify a very complex debate, while some scholars believe in a gradual, internalised transformation of society, others hold to a more abrupt process driven by the incursion of new peoples (e.g. Pohl 2000; Heather 2005; Ward Perkins 2006). Contributions from both sides of the debate are represented in the catalogue of the 2007 exhibition held in Turin (Brogiolo and Chavarria Arnau 2007). This was not a celebration of the eighth century and the 'Lombard Renaissance' but focussed instead on the period between the fourth and the seventh centuries. At its heart were questions surrounding the social 
and political implications of either cultural contact, or collision and the processes that led to the formation of multicultural societies. In the introduction to the exhibition catalogue it is openly acknowledged that the different interpretations of the migrations of Late Antiquity and the Early Middle Ages parallel, in some way, the variety of readings and opinions voiced in the public debate. Brogiolo (2007: 19) reflects on the link between historical interpretation and contemporary concerns, stating that:

\begin{abstract}
"in the contradictory interpretations of the events that marked the end of the Western Empire it is not difficult to see an echo of the contemporary debate between those who see immigration not only as an economic opportunity, but also as a chance of cultural enrichment and those who fear the risks and the uncertain outcomes."
\end{abstract}

This connection between past and present is one of the reasons that makes this period worthy of being researched and presented to the public in its complexity (Brogiolo 2007: 19).

\title{
Conclusions
}

To conclude, I have attempted to show how the major social and political changes brought about by the fall of communism in Europe have affected Italian Medieval Archaeology in more subtle, but no less profound, ways than we might have expected. Superficially, the Italian academic world, engaged in defining the themes and approaches of this new discipline, appears to have been largely uninfluenced by these events. What is clear, however, is that there was a significant change in the ways in which certain historical and archaeological narratives were presented to the wider public. The effects of social and political changes across contemporary Europe fed back into archaeological research and synthesis through the medium of public engagement, frequently providing a forum through which the (re)negotiation and projection of identities could be achieved. This aspect of public engagement cannot, therefore, be lightly dismissed from reflective analyses of archaeological theory and practice as long as we understand that archaeological and historical research is about people in the present as much as people in the past.

\section{References}

ArchMed 1974: Editoriale. Archeologia Medievale 1: 7-9.

Arslan, E.A, O. von Hessen \& C. Calderini (eds.), 1978a. I Longobardi e la Lombardia: Saggi. Milano, Palazzo Reale dal 12 Ottobre 1978. San Donato Milanese: Industrie Grafiche Fratelli Azzimonti.

Arslan, E.A, O. von Hessen \& C. Calderini (eds.) 1978b. I Longobardi e la Lombardia: Introduzione alla Mostra. Milano, Palazzo Reale dal 12 Ottobre 1978. San Donato Milanese: Industrie Grafiche Fratelli Azzimonti.

\footnotetext{
${ }^{4}$ Translation from Italian by GV.
} 
ArTIFONI, E., 2000. Ideologia e memoria locale nella storiografia italiana sui Longobardi, in: C. Bertelli \& G. P. Brogiolo (eds.), Il Futuro dei Longobardi. L'Italia e la Costruqione dell'Europa di Carlo Magno. Milan: Skira, 219-227.

Augenti, A., 2003. Archeologia medievale in Italia. Tendenze attuali e prospettive future. Archeologia Medievale 30: 511-518.

Barbiera, I., 1998. 'E ai dì remoti grande pur egli il Forogiulio appare'. Longobardi, storiografia e miti delle origini a Cividale del Friuli. Archeologia Medievale 25: 345-357.

Barbiera, I. 2012. Memorie Sepolte. Tombe e Identità nell'Alto Medioevo (Secoli V-VIII). Rome: Carocci Editore.

Bertelli, C. 2000. Lamina di Agilulfo (590-612), in: C. Bertelli \& G. P. Brogiolo (eds.), Il futuro dei Longobardi. L'Italia e la costruqione dell'Europa di Carlo Magno, Vol. 1, Milano: Skira, 100.

Bertelli, C. \& G.P. Brogiolo (eds.), 2000a. Il Futuro dei Longobardi. L'Italia e la Costruqione dell'Europa di Carlo Magno. 18 Giugno - 19 Novembre 2000. Brescia-Santa Giulia. Catalogo. Milan: Skira.

Bertelli, C. \& G. P. Brogiolo (eds.), 2000b. Il Futuro dei Longobardi. L'Italia e la Costruzione dell'Europa di Carlo Magno. 18 Giugno - 19 Novembre 2000. Brescia-Santa Giulia. Saggi. Milan: Skira.

Brogiolo, G. P. (ed.), 1984. Archeologia Urbana in Lombardia. Valutazione dei Depositi Archeologici e Inventario dei Vincoli. Modena: Panini.

Brogiolo, G. P., 1987. A proposito dell'organizzazione urbana nell'altomedioevo. Archeologia Medievale 14: 27-46.

Brogiolo, G. P. (ed.), 1995. Città, Castelli, Campagne nei Territori di Frontiera (VI-VII secolo). $5^{\circ}$ Seminario sul Tardoantico e l'Altomedioevo in Italia Centrosettentrionale. Mantua: Società Archeologica Padana.

Brogiolo, G. P. (ed.), 1996. La Fine delle Ville Romane: Trasformazioni nelle Campagne tra Tarda Antichità e Alto Medioevo. $1^{\circ}$ Convegno Archeologico del Garda. Gardone Riviera (BS) 14 Ottobre 1995. Mantua: Società Archeologica Padana.

Brogiolo, G. P., 2007. I Longobardi all'alba dell'Italia dalla caduta dell'Impero romano agli stati romano-barbarici, in: G. P. Brogiolo \& A. Chavarria Arnau (eds.), I Longobardi. Dalla Caduta dell'Impero Romano all' Alba dell'Italia. Milan: Silvana Editoriale, 15-19.

Brogiolo, G. P., 2009. Italian Medieval Archaeology: recent developments and contemporary challenges, in: R. GiLChRIST \& P. REYNOLDS (eds.), Reflections: 50 Years of Medieval Archaeology, 1957-2007. Leeds: Maney Publishing, 155-171.

Brogiolo, G.P. \& G. Cantino Wataghin (eds.), 1998. Sepolture tra IV e VIII Secolo. Atti del $7^{\circ}$ Seminario sul Tardo Antico e L'Alto Medioevo in Italia Centro-settentrionale. Gardone, 2426 ottobre 1996. Mantua: Società Archeologica Padana.

Brogiolo, G. P. \& A. Chavarria Arnau (eds.), 2007. I Longobardi. Dalla Caduta dell'Impero Romano all'Alba dell'Italia. Milan: Silvana Editoriale.

Cavanna, A., 1978. La civiltà giuridica longobarda, in: E. A. Arslan, O. von Hessen \& C. Calderini (eds.), I Longobardi e la Lombardia: Saggi. Milano, Palazzo Reale dal 12 Ottobre 1978. San Donato Milanese: Industrie Grafiche Fratelli Azzimonti, 1-34.

Delogu, P., 1980. Il regno longobardo, in: P. Delogu, A. Guillou \& G. Ortalli (eds.), Longobardi e Bizantini. Turin: UTET, 3-216.

Delogu, P., 1986. Archeologia medievale: un bilancio di vent'anni. Archeologia Medievale 13: 493-505. 
Francovich, R. \& G. NoYÉ (eds.). 1994, La Storia dell' Altomedioevo Italiano (VI-X secolo) alla Luce dell'A rcheologia. Atti del Convegno Internazionale (Siena 1992). Florence: All'Insegna del Giglio. Francovich, R. \& M. Milanese (eds.), 1990. Lo Scavo Archeologico di Montarrenti e i Problemi dell'Incastellamento Medievale: Esperienze a Confronto. Florence: All'Insegna del Giglio.

FALCo, G. 1952. La questione longobarda e la moderna storiografia italiana, in: Atti del Primo Congresso Internazionale di Studi Longobardi (Spoleto 27-30 settembre 1951). Spoleto: Centro Italiano di Studi sull'Alto Medioevo, 154-166.

Gasparri, S., 2005. La memoria storica dei Longobardi, in: C. Azzara \& S. Gasparri (eds.), Le Leggi dei Longobardi. Storia, Memoria e Diritto di un Popolo Germanico. Second Edition. XVII-XXXIV. Rome: Viella.

Gelichi, S., 1997. Introduzione all'Archeologia Medievale. Storia e ricerca in Italia. Rome: Carocci Editore.

Gelichi, S., 2011. Archeologia Medievale. Intervento introduttivo, in: G. M. VARAnINI (ed.) Intorno alla Storia Medievale. Archeologia Medievale, Storia dell'Arte Medievale, Antropologia Culturale. Atti dell'Incontro Organizzato dalla Società Italiana degli Storici Medievisti (Roma 1-2 Ottobre 2010). Reti Medievali 12 (2): 5-15.

GeLichi, S., 2015. Il 'canto delle sirene' e l'Archeologia Medievale del futuro, in: S. Gelichi (ed.), Quarant'Anni di Archeologia Medievale in Italia. La Rivista, i Temi, la Teoria e i Metodi. Archeologia Medievale, Numero Speciale. Florence: All'Insegna del Giglio, 7-9.

Gramsch, A., 2000. 'Reflexiveness' in archaeology, nationalism and Europeanism. Archaeological Dialogues 7 (1): 4-19.

Gramsch, A., 2013. Archaeology, the public, and Europeanism. Caught falling between two chairs? in: D. Callebaut, J. MaŘík \& J. MaŘíkovÁ-Kubková (eds.), Heritage Reinvents Europe. Proceedings of the Internationale Conference. Ename, Belgium, 17-19 March 2011. Ename: Europae Archaeologiae Consilium (EAC), Association Internationale sans But Lucratif (AISBL), 25-32.

Gundle, S. \& S. Parker (eds.), 1996. The New Italian Republic. From the Fall of the Berlin Wall to Berlusconi. London and New York: Routledge.

Hessen von, O., 1990. Il processo di romanizzazione, in: G. C. Menis (ed.), I Longobardi. Catalogo della Mostra (Cividale del Friuli-Codroipo 2 gingno-30 settembre 1990). Milan: Electa, 222-234.

Heather, P., 2005. The Fall of the Roman Empire. London: Macmillan.

Hudson, P., 1981. Archeologia Urbana e Programmazione della Ricerca: l'Esempio di Pavia. Florence: All'Insegna del Giglio.

KuRze,W., 1980. La lamina di Agilulfo: usurpazione o diritto? in: Longobardi e Lombardia: Aspetti della Civiltà Longobarda. Atti del VI Congresso di Studi sull'Alto Medioevo (Milano 21 25 Ottobre 1978). Spoleto: Fondazione Centro Italiano di Studi sull'Alto Medioevo, $447-456$.

La Rocca, C., 1986. 'Dark Ages' a Verona. Edilizia privata, aree aperte e strutture pubbliche in una città dell'Italia settentrionale. Archeologia Medievale 13: 31-78.

La Rocca, C., 2008. Antenati, distruttori, semplicemenete inetti. I Longobardi nella storiografia locale tra otto e novecento. Annales de Historia Antigua, Medieval Y Moderna 40: $1-12$.

Marin, J. Y., 2001. How Europe is portrayed in exhibitions. Museum International. The Hidden Facets of Exbibition LIII (3): 4-7. 
Menis, G. C. (ed.), 1990a. I Longobardi. Catalogo della Mostra (Cividale del Friuli-Codroipo 2 gingno-30 settembre 1990). Milan: Electa.

Menis, G. C., 1990b. Introduzione, in: G. C. Menis (ed.), I Longobardi. Catalogo della Mostra (Cividale del Friuli-Codroipo 2 gingno-30 settembre 1990). Milan: Electa, 5-11.

NikLasson, E., 2013. Archaeology as European Added Value, in: E. NikLasson \& T. Meier (eds.), Appropriate narratives. Archaeologists, publics and stories. Budapest: Archaeolingua Alapítvány, 49-86.

Pani Ermini, L., 2000. Archeologia Medievale, in Enciclopedia Italiana Treccani. Appendice VI. Rome: Istituto dell'Enciclopedia Italiana, 83-85.

Pavan, G., 1990. Architettura del periodo longobardo, in: G. C. Menis (ed.), I Longobardi. Catalogo della Mostra (Cividale del Friuli-Codroipo 2 gingno-30 settembre 1990). Milan: Electa, 236-298.

PoHL, W., 2000. Le Origini Etniche dell'Europa: Barbari e Romani tra Antichità e Medioevo. Rome: Viella.

Pugliese Carratelli, G. (ed.), 1984. Magistra Barbaritas. I Barbari in Italia. XIII. Milan: Libri Sheiwiller.

RotiLI, M., 2010. I Longobardi: migrazione, etnogenesi e insediamento, in: G. RomA (ed.), I Longobardi del Sud. Rome: Giorgio Bretschneider, 1-77.

Scardigli P., 1990. Dalla cultura orale alla cultura scritta, in: G. C. Menis (ed.), I Longobardi. Catalogo della Mostra (Cividale del Friuli-Codroipo 2 gingno-30 settembre 1990). Milan: Electa, 153-163.

SHOre, C., 2006. "In uno plures" (?) EU cultural policy and the governance of Europe. Cultural Analysis 5: 7-26.

Tzanidaki, J. D., 2000. Rome, Maastricht and Amsterdam. The common European heritage. Archaeological Dialogues 71 (1): 20-33.

Unesco CNI. Procedura Concordata per l'invio di candidature nelle liste e nei network dell'UNESCO. Accessed 31 Mar 2016.

http://www.unesco.it/cni/index.php/candidature.

Unesco 2011a. The Longobards in Italy. Places of Power (568-774 AD). 2011. UNESCO World Heritage List. Nomination Format. Accessed 31 March 2016. http://whc.unesco.org/en/list/1318/multiple=1\&unique_number=1780.

Unesco 2011b. The Longobards in Italy. Places of Power (568-774 AD). 2011. UNESCO World Heritage List. Nomination Format. Accessed 29 March 2016.

http://whc.unesco.org/en/list/1318.

Unione Europea 1990-1999, Un'unione senza frontiere. Accessed 30 Mar 2015.

http://europa.eu/about-eu/eu-history/1990-1999/index_it.htm.

Ward Perkins, B., 2006. The Fall of Rome and the End of Civilization. Oxford: Oxford University Press.

Wood, I., 2013. The Modern Origins of the Early Middle Ages. Oxford: Oxford University Press. 